\title{
3 Research S Suare \\ Screening and in Vitro Validation of Mushroom Derived Compounds Against SARS-CoV-2
}

\section{Mohammad Hassan Baig}

Yonsei University College of Medicine

Ayman Turk

Chungbuk National University

Mohd Imran Khan

Yonsei University College of Medicine

Jae-June Dong

Yonsei University College of Medicine

Dae Hee Lee

DOOBON INC, 59, Hwangtanri-gil, Gangnae-myeon, Heungdeok-gu, Cheongju-si, Chungbuk

\section{Young Guk Kim}

DOOBON INC, 59, Hwangtanri-gil, Gangnae-myeon, Heungdeok-gu, Cheongju-si, Chungbuk

\section{Mi Kyeong Lee}

Chungbuk National University

Jae-Yong Cho ( $D$ CHOJY@yuhs.ac)

Yonsei University College of Medicine

\section{Research Article}

Keywords: Mushroom, COVID-19, Cordycepin, C. militaris

Posted Date: March 3rd, 2022

DOI: https://doi.org/10.21203/rs.3.rs-1390476/v1

License: (c) (i) This work is licensed under a Creative Commons Attribution 4.0 International License.

Read Full License 


\section{Abstract}

It's been more than 2 years since the first outbreak of COVID-19, and still the pandemic is devastating the world and is standing as significant threat to the worldwide medical settings. The reports of new variants, absence of globally approved therapeutics are the major reasons responsible for the continuously increasing number of cases and mortalities. The main protease (Mpro) of SARS-CoV-2 is a well reported and a key therapeutic target for designing drugs to treat COVID-19. The medicinal properties of mushrooms and its derived natural compounds are well established. Here in this study, we have performed the virtual screening of mushroom-derived compounds against the SARS-CoV-2 Mpro. Cordycepin was found to be the most active compound against Mpro. The compound was further isolated from $C$. militaris and in vitro assay was performed to confirm its antivirals potential against SARS-CoV-2. Our findings show cordycepin to be a promising candidate against COVID-19.

\section{Introduction}

Over the past few decades, coronavirus has posed a severe threat to public health [1-3]. The SARS (Severe Acute Respiratory Syndrome) and MERS (Middle East Respiratory Syndrome), reported in 2003 and 2012, respectively, were the first family members [4-8]. SARS-CoV-2, the new member of this family, is considered the worst of all and is responsible for the recent global pandemic. The disease caused by SARS-CoV-2 is termed Coronavirus disease 2019 (COVID-19) has spread all over the globe [9,10]. COVID19 , the ongoing pandemic disease, has severely affected the global medical settings $[11,12]$. SARS-CoV-2, the positive-sense single-stranded RNA virus, is responsible for this pandemic. This newly identified member of coronaviridae family was first reported in Wuhan in $2019[13,14]$. Declared as a global pandemic by World Health Organization (WHO) on February 11, 2020 [15,16], this disease has rapidly spread all over the world and has accounted for over a million of deaths. Today, a large portion of the human population suffers from this viral disease and has accounted for over a million deaths $[17,18]$. Although intense research and development towards developing potential therapeutic are ongoing worldwide, searching for a broad-spectrum antiviral is still a milestone [19-23].

The emergence of novel SARS-CoV-2 variants has fueled the already persisting challenge. These new variants are reported to increase the transmissibility and increase their ability to escape antibody neutralization [22-24].

The search for effective and safe therapeutics is an urgent need and a significant challenge as well.

From viral entry to its replication, the life cycle of SARS-CoV-2 comprises several major checkpoints [25]. Therefore, the targeting of these checkpoints is an effective way to control this pandemic.

Comprising of 14 open reading frames (ORFs), SARS-CoV-2 genome encodes polyprotein precursors (pp1a and pp1ab), four structural (spike, envelope, nucleocapsid, and membrane protein) and accessory proteins [26-28]. SARS-CoV-2, a 29,903 bp ss RNA sharing 82\% identity with severe acute respiratory syndrome coronavirus (SARS-CoV), also belongs to the clade b of the genus betacoronavirus [29]. The 
four essential proteins of SARS-CoV-2, viz. Spike, PLpro, Mpro, and RdRP are crucial players required to infect and replicate the virus [30]. These vital roles played by these proteins make them a suitable therapeutic target. Among all, Mpro has widely been characterized as the primary target for the design of small molecule inhibitors regulating viral replication [31,32]. The two polyproteins (pp1a/pp1ab) cleave into individual nonstructural proteins to replicate the viral genome. This cleavage of $p p 1 a / p p 1 a b$ is performed by main protease (Mpro) and papain-like protease [25]. Thus, the essential characteristics and role make these viral proteases important antiviral targets [33-35]. Notably, the cleavage specificity of Mpro is not displayed by any known human protease, thereby targeting SARS-CoV-2 Mpro reduce potential side effects [35,36].

Findings have well established the various medicinal properties of the mushroom [37-39] [Figure 1]. Its antiviral, antibacterial, and anti-inflammatory effects are well reported [40,41]. Studies have well reported the antiviral potential of mushrooms with a reduced chance of adverse side effects [41]. In this study, we have performed the virtual screening of mushroom-derived compounds against the SARS-CoV-2 Mpro [Table 1]. As a result of several deep investigations, cordycepin was the most active compound against Mpro. Cordycepin was further studied for experimentally validating its SARS-CoV-2 inhibitory potential. Cordycepin was isolated from the $C$. militaris. Further, the affinity of cordycepin was in vitro evaluated in

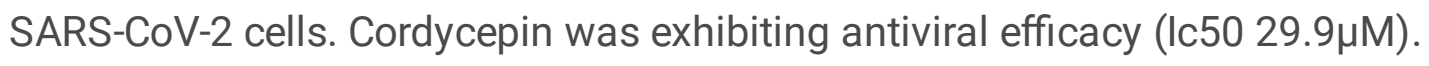

\section{Results And Discussion}

The repurposing or repositioning of drugs have proved their potential against the new emerging viral diseases [42-45]. The approach has also provided a large opportunity in translational research. The repositioning of already reported molecules especially against viruses substantially increases the success probability and is effective in terms of time, cost, and clinical availability $[46,47]$.

A large number of studies showed the presence of several bioactive compounds including, flavonoid, terpenoids, lectins, phenolic, and polysaccharides [48-51]. These compounds are well reported to be responsible for their use as antiviral, antitumoral, anti-inflammatory, antioxidant, antifungal, and immunostimulatory agent in modern medicine [48,52]. The previous research reports inspired us to study the impact of mushroom against SARS-CoV-2. Here in this study, we evaluated the affinity of some important components of $C$. militaris against MPro. Mpro was selected because of its prominent role in SARS-CoV-2 replication [53]. Main protease (Mpro, 3CLpro), a 306 amino acid long protein is a wellstudied and an alluring therapeutic target [45]. The inhibition of this protein forestalls the viral replication by restraining the polyprotein cleavage $[32,54,55]$.

All the major compounds from the $C$. militaris were screened against Mpro (Table 1 ). The top molecule was selected based on the binding of the binding affinity. Demonstrating the PLP fitness score of 52.02, Cordycepin was found to be the most active compound against Mpro (Table 1). The antiviral activity of cordycepin is well documented in previous studies [56-58]. Further investigation highlighted the role of some important active site residues of Mpro, involved in accommodating all the compounds. 
The study shows several active site residues H41, N142, H162, H164, E166, D187, and R188 to be prominently involved in making hydrogen bonds (Fig. 2 and Table 1). Along with several other residues were contributing in accommodating the molecules by making hydrophobic interactions or pi-cation interaction. The role of these residues has been discussed earlier as well $[32,35,59]$. 
Table 1

Detailed interaction of all the compounds within the active site of Mpro.

\begin{tabular}{|c|c|c|c|c|}
\hline Compound & $\begin{array}{l}\text { ClemPLP } \\
\text { Score }\end{array}$ & Bond & Distance & Type \\
\hline \multirow[t]{4}{*}{ Cordyrrole A } & \multirow[t]{4}{*}{38.35} & $\begin{array}{l}\text { C01:H4 - } \\
\text { ASN142:OD1 }\end{array}$ & 2.20 & $\begin{array}{l}\text { Hydrogen } \\
\text { Bond }\end{array}$ \\
\hline & & $\begin{array}{l}\text { GLU166:HN - } \\
\text { C01:03 }\end{array}$ & 2.15 & $\begin{array}{l}\text { Hydrogen } \\
\text { Bond }\end{array}$ \\
\hline & & C01 - CYS145 & 4.90 & Pi-Alkyl \\
\hline & & HIS163 - C01 & 5.05 & Pi-Alkyl \\
\hline \multirow[t]{6}{*}{$\begin{array}{l}\text { 2-Hydroxy-1-[1-(2-hydroxyethyl)-1H-pyrrol- } \\
\text { 2-yl]-ethanone }\end{array}$} & \multirow[t]{6}{*}{42.68} & $\begin{array}{l}\text { ARG188:HN - } \\
\text { C02:02 }\end{array}$ & 2.65 & $\begin{array}{l}\text { Hydrogen } \\
\text { Bond }\end{array}$ \\
\hline & & $\begin{array}{l}\text { C02:H8 - } \\
\text { ASP187:0 }\end{array}$ & 2.57 & $\begin{array}{l}\text { Hydrogen } \\
\text { Bond }\end{array}$ \\
\hline & & $\begin{array}{l}\text { C02:H11 - } \\
\text { ARG188:0 }\end{array}$ & 1.80 & $\begin{array}{l}\text { Hydrogen } \\
\text { Bond }\end{array}$ \\
\hline & & $\begin{array}{l}\text { ARG188:HA - } \\
\text { C02:01 }\end{array}$ & 2.47 & $\begin{array}{l}\text { Hydrogen } \\
\text { Bond }\end{array}$ \\
\hline & & HIS41:NE2 - C02 & 4.43 & Pi-Cation \\
\hline & & C02 - MET49 & 4.86 & Pi-Alkyl \\
\hline \multirow[t]{8}{*}{ Nicotinamide } & \multirow[t]{8}{*}{36.39} & $\begin{array}{l}\text { C03:N1- } \\
\text { ASP187:OD2 }\end{array}$ & 5.08 & $\begin{array}{l}\text { Attractive } \\
\text { Charge }\end{array}$ \\
\hline & & $\begin{array}{l}\text { C03:H6 - } \\
\text { HIS164:O }\end{array}$ & 1.64 & $\begin{array}{l}\text { Hydrogen } \\
\text { Bond }\end{array}$ \\
\hline & & $\begin{array}{l}\text { C03:H3 - } \\
\text { ASP187:0 }\end{array}$ & 2.42 & $\begin{array}{l}\text { Hydrogen } \\
\text { Bond }\end{array}$ \\
\hline & & $\begin{array}{l}\text { CO3:H4 - } \\
\text { HIS164:O }\end{array}$ & 2.57 & $\begin{array}{l}\text { Hydrogen } \\
\text { Bond }\end{array}$ \\
\hline & & HIS41:NE2 - C03 & 4.69 & Pi-Cation \\
\hline & & C03:N1 - HIS41 & 4.00 & Pi-Cation \\
\hline & & HIS41 - C03 & 4.18 & $\begin{array}{l}\text { Pi-Pi } \\
\text { Stacked }\end{array}$ \\
\hline & & C03 - MET49 & 4.62 & Pi-Alkyl \\
\hline \multirow[t]{2}{*}{ 3,5-Dihydroxy-4-methoxybenzyl alcohol } & \multirow[t]{2}{*}{42.17} & $\begin{array}{l}\text { C04:H7 - } \\
\text { ARG188:O }\end{array}$ & 1.97 & $\begin{array}{l}\text { Hydrogen } \\
\text { Bond }\end{array}$ \\
\hline & & $\begin{array}{l}\text { C04:H10 - } \\
\text { ASP187:O }\end{array}$ & 2.10 & $\begin{array}{l}\text { Hydrogen } \\
\text { Bond }\end{array}$ \\
\hline
\end{tabular}




\begin{tabular}{|c|c|c|c|c|}
\hline Compound & $\begin{array}{l}\text { ClemPLP } \\
\text { Score }\end{array}$ & Bond & Distance & Type \\
\hline & & $\begin{array}{l}\text { C04:H5- } \\
\text { GLN189:OE1 }\end{array}$ & 2.81 & $\begin{array}{l}\text { Hydrogen } \\
\text { Bond }\end{array}$ \\
\hline & & $\begin{array}{l}\text { MET } 165: S D \text { - } \\
\text { C04:03 }\end{array}$ & 3.23 & Sulfur-X \\
\hline & & HIS41 - C04 & 5.10 & $\begin{array}{l}\text { Pi-Pi T- } \\
\text { shaped }\end{array}$ \\
\hline & & $\begin{array}{l}\text { C04:C7 - } \\
\text { MET165 }\end{array}$ & 5.40 & Alkyl \\
\hline & & C04 - MET49 & 5.33 & Pi-Alkyl \\
\hline & & C04 - MET165 & 5.02 & Pi-Alkyl \\
\hline \multirow[t]{9}{*}{ Adenosine } & 45.69 & $\begin{array}{l}\text { SER144:HG - } \\
\text { C05:02 }\end{array}$ & 2.22 & $\begin{array}{l}\text { Hydrogen } \\
\text { Bond }\end{array}$ \\
\hline & & $\begin{array}{l}\text { C05:H12 - } \\
\text { GLU166:OE2 }\end{array}$ & 2.02 & $\begin{array}{l}\text { Hydrogen } \\
\text { Bond }\end{array}$ \\
\hline & & $\begin{array}{l}\text { C05:H13 - } \\
\text { PHE140:O }\end{array}$ & 2.98 & $\begin{array}{l}\text { Hydrogen } \\
\text { Bond }\end{array}$ \\
\hline & & $\begin{array}{l}\text { C05:H13 - } \\
\text { GLU166:OE2 }\end{array}$ & 1.95 & $\begin{array}{l}\text { Hydrogen } \\
\text { Bond }\end{array}$ \\
\hline & & $\begin{array}{l}\text { HIS172:HD2 - } \\
\text { C05:04 }\end{array}$ & 2.95 & $\begin{array}{l}\text { Hydrogen } \\
\text { Bond }\end{array}$ \\
\hline & & $\begin{array}{l}\text { C05:H1 - } \\
\text { GLU166:0 }\end{array}$ & 2.54 & $\begin{array}{l}\text { Hydrogen } \\
\text { Bond }\end{array}$ \\
\hline & & $\begin{array}{l}\text { C05:H10 - } \\
\text { ASN142:OD1 }\end{array}$ & 2.65 & $\begin{array}{l}\text { Hydrogen } \\
\text { Bond }\end{array}$ \\
\hline & & C05:N3 - HIS41 & 4.4 & Pi-Cation \\
\hline & & C05 - MET165 & 5.15 & Pi-Alkyl \\
\hline \multirow[t]{6}{*}{ Cordycepin } & 52.02 & $\begin{array}{l}\text { C06:H13 - } \\
\text { MET49:0 }\end{array}$ & 1.51 & $\begin{array}{l}\text { Hydrogen } \\
\text { Bond }\end{array}$ \\
\hline & & $\begin{array}{l}\text { PR052:HD2 - } \\
\text { C06:03 }\end{array}$ & 2.5 & $\begin{array}{l}\text { Hydrogen } \\
\text { Bond }\end{array}$ \\
\hline & & $\begin{array}{l}\text { C06:H6- } \\
\text { ARG188:O }\end{array}$ & 1.9 & $\begin{array}{l}\text { Hydrogen } \\
\text { Bond }\end{array}$ \\
\hline & & C06 - MET165 & 5.4 & Alkyl \\
\hline & & HIS41 - C06 & 4.70 & Pi-Alkyl \\
\hline & & MET165 - C06 & 4.14 & Pi-Alkyl \\
\hline
\end{tabular}




\begin{tabular}{|c|c|c|c|c|}
\hline Compound & $\begin{array}{l}\text { ClemPLP } \\
\text { Score }\end{array}$ & Bond & Distance & Type \\
\hline & & C06 - MET165 & 5.13 & Pi-Alkyl \\
\hline \multirow[t]{9}{*}{ 2'-0-methyladenosine } & \multirow[t]{9}{*}{48.54} & $\begin{array}{l}\text { SER144:HG - } \\
\text { C07:02 }\end{array}$ & 2.11 & $\begin{array}{l}\text { Hydrogen } \\
\text { Bond }\end{array}$ \\
\hline & & $\begin{array}{l}\text { C07:H10 - } \\
\text { ASN142:OD1 }\end{array}$ & 1.97 & $\begin{array}{l}\text { Hydrogen } \\
\text { Bond }\end{array}$ \\
\hline & & $\begin{array}{l}\text { MET165:HA - } \\
\text { C07:01 }\end{array}$ & 2.57 & $\begin{array}{l}\text { Hydrogen } \\
\text { Bond }\end{array}$ \\
\hline & & $\begin{array}{l}\text { C07:H1 - } \\
\text { GLU166:0 }\end{array}$ & 2.63 & $\begin{array}{l}\text { Hydrogen } \\
\text { Bond }\end{array}$ \\
\hline & & $\begin{array}{l}\text { C07:H5 - } \\
\text { LEU141:0 }\end{array}$ & 2.82 & $\begin{array}{l}\text { Hydrogen } \\
\text { Bond }\end{array}$ \\
\hline & & C07:N3 - HIS41 & 3.99 & Pi-Cation \\
\hline & & HIS41 - C07 & 4.81 & $\begin{array}{l}\text { Pi-Pi T- } \\
\text { shaped }\end{array}$ \\
\hline & & C07 - MET165 & 4.42 & Pi-Alkyl \\
\hline & & C07 - CYS145 & 5.49 & Pi-Alkyl \\
\hline \multirow[t]{5}{*}{ Xanthosine } & \multirow[t]{5}{*}{45.05} & $\begin{array}{l}\text { C08:H10 - } \\
\text { HIS164:O }\end{array}$ & 2.09 & $\begin{array}{l}\text { Hydrogen } \\
\text { Bond }\end{array}$ \\
\hline & & $\begin{array}{l}\text { C08:H11 - } \\
\text { HIS164:0 }\end{array}$ & 2.23 & $\begin{array}{l}\text { Hydrogen } \\
\text { Bond }\end{array}$ \\
\hline & & $\begin{array}{l}\text { C08:H3 - } \\
\text { GLN189:OE1 }\end{array}$ & 2.43 & $\begin{array}{l}\text { Hydrogen } \\
\text { Bond }\end{array}$ \\
\hline & & C08 - CYS145 & 5.03 & Pi-Alkyl \\
\hline & & C08 - MET165 & 5.49 & Pi-Alkyl \\
\hline \multirow[t]{5}{*}{ Uridine } & \multirow[t]{5}{*}{45.86} & $\begin{array}{l}\text { SER144:HG - } \\
\text { C09:06 }\end{array}$ & 2.96 & $\begin{array}{l}\text { Hydrogen } \\
\text { Bond }\end{array}$ \\
\hline & & $\begin{array}{l}\text { CYS145:SG - } \\
\text { C09:06 }\end{array}$ & 3.43 & $\begin{array}{l}\text { Hydrogen } \\
\text { Bond }\end{array}$ \\
\hline & & $\begin{array}{l}\text { GLU166:HN - } \\
\text { C09:02 }\end{array}$ & 1.91 & $\begin{array}{l}\text { Hydrogen } \\
\text { Bond }\end{array}$ \\
\hline & & $\begin{array}{l}\text { C09:H10 - } \\
\text { PHE140:0 }\end{array}$ & 2.95 & $\begin{array}{l}\text { Hydrogen } \\
\text { Bond }\end{array}$ \\
\hline & & $\begin{array}{l}\text { C09:H10 - } \\
\text { GLU166:OE2 }\end{array}$ & 1.93 & $\begin{array}{l}\text { Hydrogen } \\
\text { Bond }\end{array}$ \\
\hline
\end{tabular}




\begin{tabular}{|c|c|c|c|c|}
\hline Compound & $\begin{array}{l}\text { ClemPLP } \\
\text { Score }\end{array}$ & Bond & Distance & Type \\
\hline & & $\begin{array}{l}\text { C09:H11 - } \\
\text { GLU166:OE2 }\end{array}$ & 1.94 & $\begin{array}{l}\text { Hydrogen } \\
\text { Bond }\end{array}$ \\
\hline & & $\begin{array}{l}\text { HIS172:HD2 - } \\
\text { C09:05 }\end{array}$ & 2.94 & $\begin{array}{l}\text { Hydrogen } \\
\text { Bond }\end{array}$ \\
\hline & & $\begin{array}{l}\text { C09:H5 - } \\
\text { GLU166:OE2 }\end{array}$ & 3.09 & $\begin{array}{l}\text { Hydrogen } \\
\text { Bond }\end{array}$ \\
\hline \multirow[t]{8}{*}{ 2'-deoxyuridine } & \multirow[t]{8}{*}{48.81} & $\begin{array}{l}\text { C10:H11 - } \\
\text { THR190:O }\end{array}$ & 1.91 & $\begin{array}{l}\text { Hydrogen } \\
\text { Bond }\end{array}$ \\
\hline & & $\begin{array}{l}\text { C10:H12 - } \\
\text { THR190:O }\end{array}$ & 1.72 & $\begin{array}{l}\text { Hydrogen } \\
\text { Bond }\end{array}$ \\
\hline & & $\begin{array}{l}\text { C10:H2 - } \\
\text { ARG188:O }\end{array}$ & 2.25 & $\begin{array}{l}\text { Hydrogen } \\
\text { Bond }\end{array}$ \\
\hline & & $\begin{array}{l}\text { C10:H4 - } \\
\text { GLU166:0 }\end{array}$ & 2.97 & $\begin{array}{l}\text { Hydrogen } \\
\text { Bond }\end{array}$ \\
\hline & & $\begin{array}{l}\text { C10:H5 - } \\
\text { GLU166:0 }\end{array}$ & 2.29 & $\begin{array}{l}\text { Hydrogen } \\
\text { Bond }\end{array}$ \\
\hline & & $\begin{array}{l}\text { C10:H9- } \\
\text { THR190:O }\end{array}$ & 2.91 & $\begin{array}{l}\text { Hydrogen } \\
\text { Bond }\end{array}$ \\
\hline & & C10 - MET165 & 4.68 & Alkyl \\
\hline & & C10 - MET165 & 4.41 & Pi-Alkyl \\
\hline \multirow[t]{6}{*}{ Uracil } & \multirow[t]{6}{*}{29.54} & $\begin{array}{l}\text { C12:H3 - } \\
\text { GLN189:OE1 }\end{array}$ & 2.22 & $\begin{array}{l}\text { Hydrogen } \\
\text { Bond }\end{array}$ \\
\hline & & $\begin{array}{l}\text { C12:H4 - } \\
\text { HIS164:O }\end{array}$ & 1.96 & $\begin{array}{l}\text { Hydrogen } \\
\text { Bond }\end{array}$ \\
\hline & & $\begin{array}{l}\text { ASP187:HA - } \\
\text { C12:01 }\end{array}$ & 2.89 & $\begin{array}{l}\text { Hydrogen } \\
\text { Bond }\end{array}$ \\
\hline & & HIS41:NE2 - C12 & 4.59 & Pi-Cation \\
\hline & & HIS41 - C12 & 4.31 & $\begin{array}{l}\text { Pi-Pi } \\
\text { Stacked }\end{array}$ \\
\hline & & C12 - MET49 & 4.93 & Pi-Alkyl \\
\hline
\end{tabular}

Further investigations were performed to confirm the affinity of cordycepin against Mpro. MD simulation study was performed to assess the extent of the interaction of cordycepin with the Mpro. Here the structure of apo- and cordycepin-bound Mpro was subjected to 100 ns MD simulations. The structures were evaluated using various investigational parameters. The backbone RMSD was studied to evaluate 
the fluctuation in the Ca backbone of Mpro in presence and absence of cordycepin. It was found that the backbone of apo and cordycepin bound Mpro reached an equilibrium confirmation after 60 and $70 \mathrm{~ns}$, respectively (Fig. 3a). The RMSD of both the apo and cordycepin bound structures of Mpro were constant throughout the rest of the time period. Though the backbone RMSD of both the structures doesn't suggests a big difference in the backnone RMSD after the binding of cordycepin, the close observation shows apo form to be comparatively little stable (Fig. 3a). The radius of gyration (Rg) and SASA analysis was performed to determine the structural compactness level within the cordycepin unbound and bound structures of Mpro (Fig. 3b and c). Figure 3b shows the Rg of Ca atoms of the apo and cordycepin bound Mpro during the $100 \mathrm{~ns}$ simulation time. Rg analysis is very helpful in providing a better insight into the overall dimensions of protein [60]. As can be seen in Fig. 3b, the Rg of cordycepin bound Mpro was comparatively little higher than the apo form. This also suggests that the apo form of Mpro was slightly more stable than the cordycepin bound form. The SASA plot also indicates slightly higher value of SASA for the cordycepin bound structure of Mpro. The results of RMSD, Rg, and SASA analysis were well supporting each other. Furthermore, the analysis of RMSF show a clear difference in the fluctuation of the residues between the cordycepin bound and apo Mpro conformations (Fig. 3D).

Principal component analysis (PCA), a method that accounts for the essential dynamics [61], was employed to investigate the higher atomic motions patterns among all the motions within the cordycepin unbound and bound state of Mpro. Figure 4a shows the conformational sampling of tertiary structure for the apo, and cordycepin bound structure in the essential subspace along eigenvectors 1 and 2. It was clearly noticed from PC1 and PC2 projection that the cordycepin bound structure shows less compact cluster of stable states. The analysis depicts that the cordycepin bound Mpro covers a wide range of phase spaces (higher level of internal motions). This study indicates apo form of Mpro have comparatively fewer internal motions, indicating higher stiffness and stability of this structure.

Additionally, we plotted the free energy landscapes to understand better the apo and cordycepin bound structures of Mpro (Fig. 4b and c). The analysis was performed to study the differences in the proteinfolding patterns in both structures. A slight degree of difference projection of free energy was noticed with relatively stable conformation and energetically favored for the apo form of Mpro as a compared the cordycepin bound complex. All the investigation clearly indicates that the binding of cordycepin with Mpro slightly perturbs its conformation subsequently resulting in the inhibition of its activity.

Cordycepin which has been previously reported to be carrying several remedial properties [62,63]. Our study highlighted Cordycepin to be an interesting drug candidate for further research as anti-viral agent. Further isolation and purification of cordycepin was performed for its in vitro evaluation on the SARSCoV-2 cell lines. Our findings suggest that cordycepin not only being from an organic source, gives a CC50 of more than 50uM which is comparable to the most references drugs viz., Remdesivir and Lopinavir (Fig. 5). Its IC50 came out to be $29 \mu \mathrm{M}$, nearly halfway to its CC50, which is not surprising as it is a natural compound and not a drug by nature. It shows exemplary reduction in the viral load at different concentration used. Our findings could be further authenticated using appropriate in vivo animal models and other subsequent methods in order to provide additional therapeutic routes. 


\section{Materials And Methods \\ 2.1. Virtual screening}

The structure of SARS-CoV-2 Main Protease (Mpro) was retrieved from the RCSB protein data bank (pdb id: 6lu7) [32]. The structure of all the selected compounds were retrieved from the pubchem compound database. All the compounds were screened against the Mpro. The top scoring compound was selected based on PLP score.

\subsubsection{Molecular dynamics simulation}

The structure of Mpro and top scoring compound (cordycepin) in complex with Mpro were subjected to Molecular dynamics simulation using Gromacs (2020.04 package) [64]. The cubic box model was done in the TIP3P water molecules for solvation with a $10 \AA$ radius as its margin with the CHARMM27 force field. Ligand topology was generated with SwissParam. System was made neutral using sodium ions and chloride ions. Protein-ligand complex along with water and ions processed energy minimization using steepest descent minimization algorithm applying constant force for 50,000 steps. Isothermal and isochoric equilibration was done using Particle Mesh Ewald for long-range electrostatics for 50,000 steps. Isothermal and isobaric equilibration also was done using Particle Mesh Ewald for long-range electrostatics for 50,000 steps. MD run was done for 50 ns after two equilibrations.

\subsection{Isolation and purification of Cordycepin 2.2.1. Raw materials and chemicals}

A Jasco UV-550 and Perkin-Elmer model LE599 spectrometer were used respectively, for the measurement of UV and IR spectra. NMR spectra were recorded on a Bruker DRX 400 or $500 \mathrm{MHz}$ spectrometers using DMSO as solvent. ESIMS data was obtained on VG Autospec Ultima Mass spectrometers. HPLC grade solvents (methanol, acetonitrile, and water) were purchased from Fisher Scientific Korea.

\subsubsection{Microorganism and media}

The strain of $C$. militaris was provided from Clean and Green (Sejong, Korea). The stock culture was maintained on potato-dextrose-agar slants containing $20.0 \mathrm{~g} / \mathrm{L}$ glucose, $3.0 \mathrm{~g} / \mathrm{L} \mathrm{KH}_{2} \mathrm{PO}_{4}, 1.5 \mathrm{~g} / \mathrm{L} \mathrm{MgSO}{ }_{4}$ $7 \mathrm{H}_{2} \mathrm{O}$. Inoculated slants were incubated at $25^{\circ} \mathrm{C}$ for 7 days and then stored at $4^{\circ} \mathrm{C}$ for subculture, and then the seed culture transferred from the active slant was grown in PDA medium in a Petri dish at $25^{\circ} \mathrm{C}$ for 13 days. The inoculum was prepared by punching out $1 \mathrm{~cm}$ of PDA plate culture with a sterilized cylindrical cutter. The surface culture was started by inoculating the seed culture into a $500 \mathrm{ml}$ culture bottle, which was $8.5 \mathrm{~cm}$ in diameter and $14.0 \mathrm{~cm}$ in height.

\subsubsection{Isolation of cordycepin}


The dried $C$. militaris was extracted with $80 \%$ methanol for one night. The extract was evaporated under reduced pressure to give methanolic extract and suspended in $100 \mathrm{ml}$ water. Diaion HP-20 column was washed with water, then the column was eluted using different percentages of methanol in a gradient system $\left(\mathrm{H}_{2} \mathrm{O}: \mathrm{MeOH}=100: 0-0: 100\right)$ by increasing the amount of methanol $20 \%$ stepwise. Cordycepin was purified from the fraction eluted with $\mathrm{H}_{2} \mathrm{O}: \mathrm{MeOH}(80: 20)$ by semipreparative-HPLC. The structure was determined by the comparison with reported value.

\subsection{In vitro evaluation of Cordycepin against SARS-CoV-2 2.3.1. Viruses and cell lines}

Vero cells were obtained from the American Type Culture Collection (ATCC CCL-81) and maintained at $37^{\circ} \mathrm{C}$ with $5 \% \mathrm{CO} 2$ in Dulbecco's modified eagle medium (DMEM; Welgene), supplemented with $10 \%$ heatinactivated fetal bovine serum (FBS) and $1 \times$ antibiotic-antimycotic solution (Gibco). For Calu-3, cells were seeded at $2.0 \times 104$ cells per well in Eagle's minimum essential medium (EMEM), supplemented with $20 \%$ FBS, $1 \times$ MEM Non-Essential amino acid and 1 xantibiotic-antimycotic solution (Gibco) in black, 384-well, $\mu$ Clear plates (Greiner Bio-One), $24 \mathrm{~h}$ prior tothe experiment. SARS-CoV-2 ( $\beta \mathrm{CoV} / \mathrm{KOR} / \mathrm{KCDC03/2020)}$ was provided by Korea Centers forDisease Control and Prevention (KCDC) and was propagated in Vero cells. All experiments involvinglive SARS-CoV-2 followed the guidelines of the Korea National Institute of Health $(\mathrm{KNIH})$ usingenhanced biosafety level 3 (BSL3) containment procedures at Institut Pasteur Korea approved for use by the KCDC.

\subsubsection{Reagent}

All reagents were dissolved in dimethyl sulfoxide (DMSO) for the screening. Anti-SARS-CoV-2 N protein antibody was purchased from Sino Biological Inc. (Beijing, China). Alexa Fluor 488 goat anti-rabbit IgG (H $+\mathrm{L}$ ) secondary antibody and Hoechst 33342 were purchased from Molecular Probes. Paraformaldehyde (PFA) (32\% aqueous solution) and normal goat serum were purchased from Electron Microscopy Sciences (Hatfield, PA) and Vector Laboratories, Inc. (Burlingame, CA), respectively.

\subsubsection{Dose response curve analysis by immunofluorescence method}

Infected Vero and Calu-3 cells were subjected to evaluation of antiviral activity using an immunofluorescence-based imaging assay, labeling viral N protein of the SARS-CoV-2 within infected cells. In each assay detailed below, including dose-response assays and drug synergy assays, Vero cells were seeded at $1.2 \times 104$ cells per well in DMEM, supplemented with $2 \%$ FBS and $1 \times$ antibioticantimycotic solution (Gibco), in black, 4 384-well $\mu$ Clear plates (Greiner Bio-One) $24 \mathrm{~h}$ prior to the experiment. Ten-point DRCs were generated, with compound concentrations ranging from 0.1 to $50 \mu \mathrm{M}$. For the viral infections, plates were transferred into the BSL3 containment facility, and SARS-CoV-2 was added at multiplicity of infection (MOI) of 0.0125 . Before validation experiments with Vero cells, we examined both cell viability and cell infectivity by changing the MOI of SARS-CoV-2. MOI of 0.0125 was chosen as the best experimental condition based on the best cell viability $(91.73 \%)$ and the highest virus 
infectivity $(75.75 \%)$. For Calu-3, cells were seeded at $2.0 \times 104$ cells per well in EMEM, supplemented with $20 \%$ FBS, $1 \times$ MEM Non-Essential amino acid and 1 $\times$ antibiotic-antimycotic solution (Gibco) in black, 384well, $\mu$ Clear plates (Greiner Bio-One), $24 \mathrm{~h}$ prior to the experiment. Ten-point DRCs were generated with compound concentrations ranging from 0.1 to $50 \mu \mathrm{M}$. For viral infection, plates were transferred into the BSL-3 containment facility, and SARS-CoV-2 was added at MOI of 0.5. The Vero and Calu-3 cells were fixed at 24 hours post-infection with 4\% PFA and permeabilized with Triton-X100 to promote entering antibodies into cells.

\section{Conclusions}

SARS-CoV-2, the agent responsible for the recent global pandemic has threatened the global hospital settings. Spread all over the globe, this virus is responsible for several millions of worldwide deaths. $C$. militaris is the most valued species of Traditional Chinese Medicine considered for its various medicinal properties. Here we evaluated the potential of various compounds from $C$. militaris against the SARSCoV-2 Mpro. Cordycepin was found to be the most potential candidate against Mpro. Further in vitro evaluation also confirms the antiviral potential of these compound. The finding of this study will open doors for the use of natural compounds derived from mushrooms as an effective COVID-19 treatment.

\section{Declarations}

\section{Author Contributions:}

“Conceptualization, J.Y.C., M.K.L., and J.J.D.; methodology, M.H.B., D.H.L, Y.G.K., M.I.K., and A.T.; software, J.J.D., and J.Y.C.; validation, A.T., M.H.B., J.J.D. and M.I.K.; formal analysis, J.Y.C., M.K.L., J.J.D., and M.H.B.; investigation, M.H.B., D.H.L., Y.G.K., M.I.K., A.T., and J.J.D.; resources, J.Y.C., M.K.L., and J.J.D.; writing-original draft preparation, M.H.B., A.T., J.J.D., J.J.D., and M.K.L.; writing-review and editing, J.Y.C., M.K.L., M.H.B., and J.J.D.; supervision, J.Y.C., J.J.D., and M.K.L.; project administration, X.X.; funding acquisition, Y.Y. All authors have read and agreed to the published version of the manuscript."

\section{Funding:}

Regional Inovation Strategy (RIS)" through the National Research Foundation of Korea (NRF) funded by the Ministry of Education (MOE) (No.2021RIS0051).

\section{References}

References aren't available with this version.

\section{Figures}




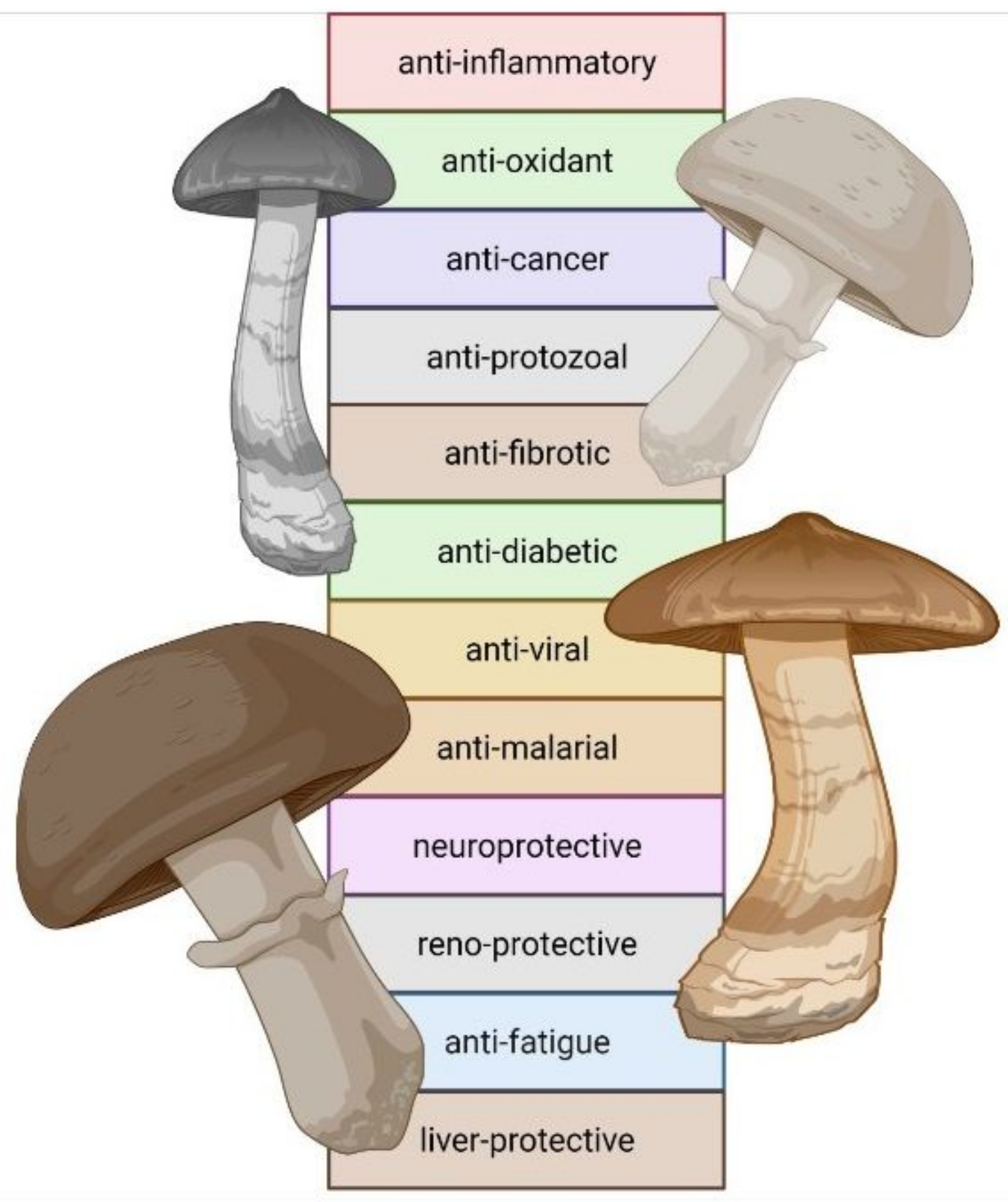

Figure 1

The medicinal uses of $C$. militaris. 


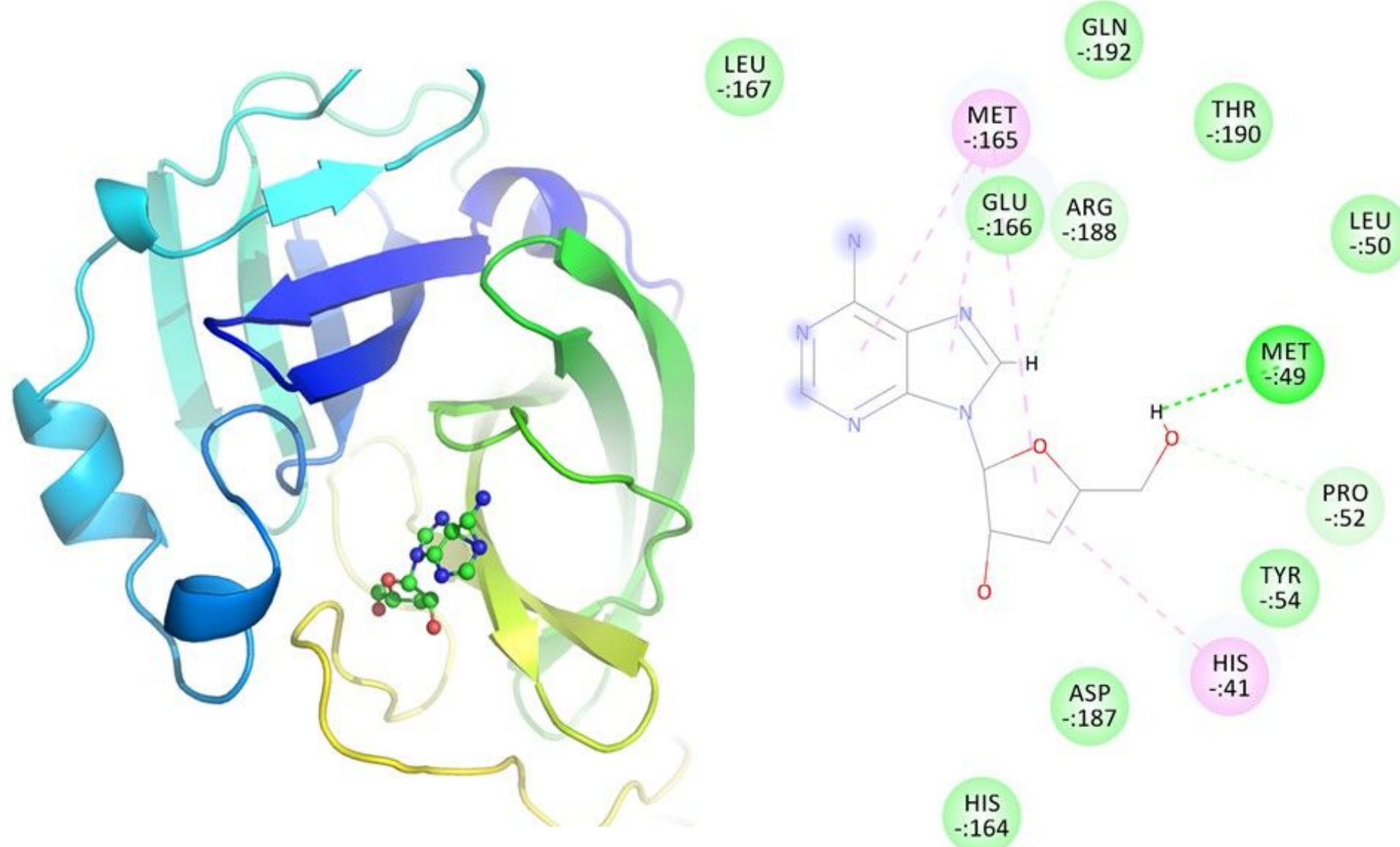

Figure 2

Docked complex of cordycepin within the active site of Mpro. 

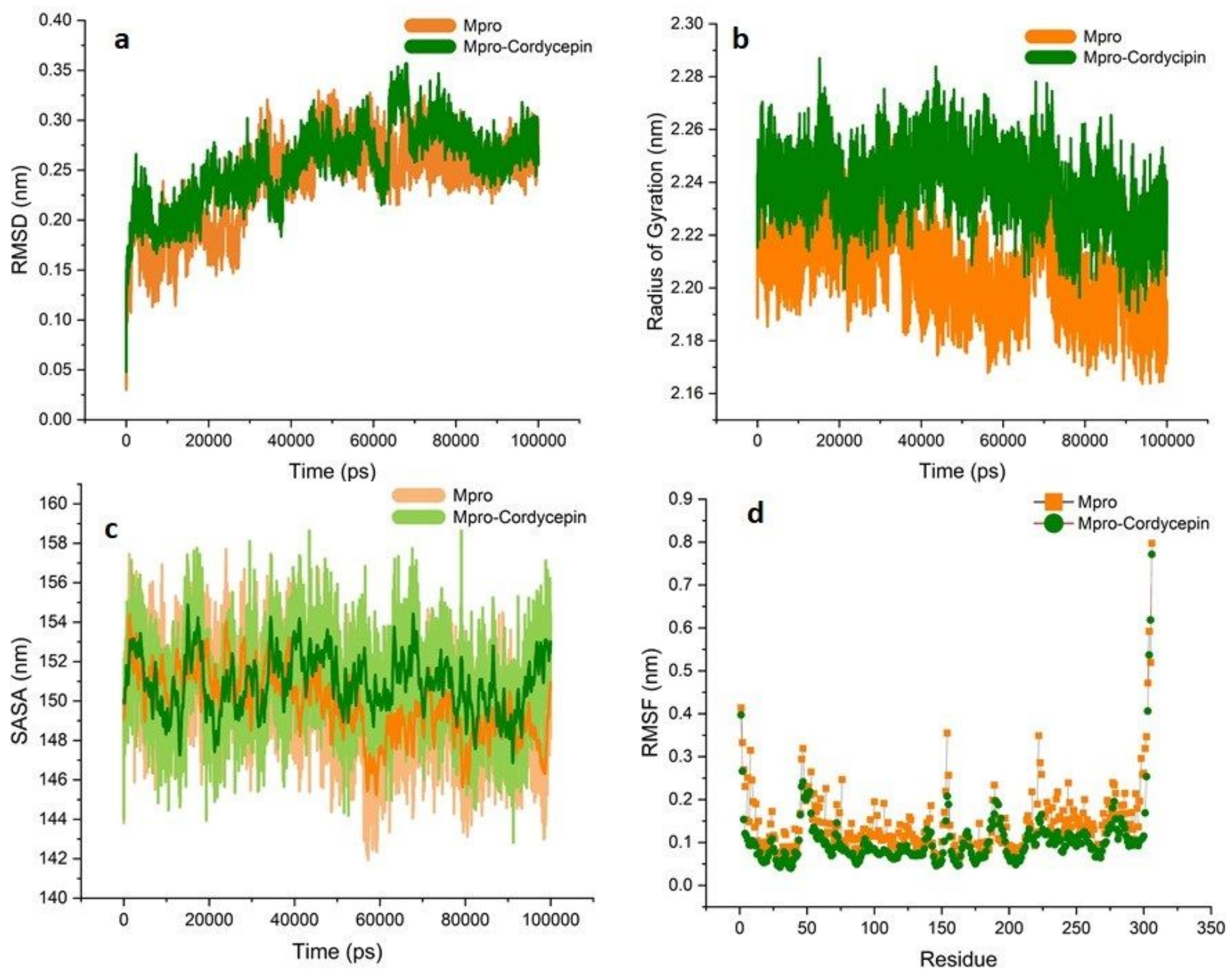

Figure 3

The molecular dynamics results for the apo and cordycepin bound structure of Mpro during the $100 \mathrm{~ns}$ (a) The backbone RMSD of apo and cordycepin bound Mpro (b) The radius of gyration and (c) SASA of the apo and cordycepin bound Mpro (d) The root mean square fluctuation of the residues in the apo and cordycepin bound states of Mpro during the 100 ns. 


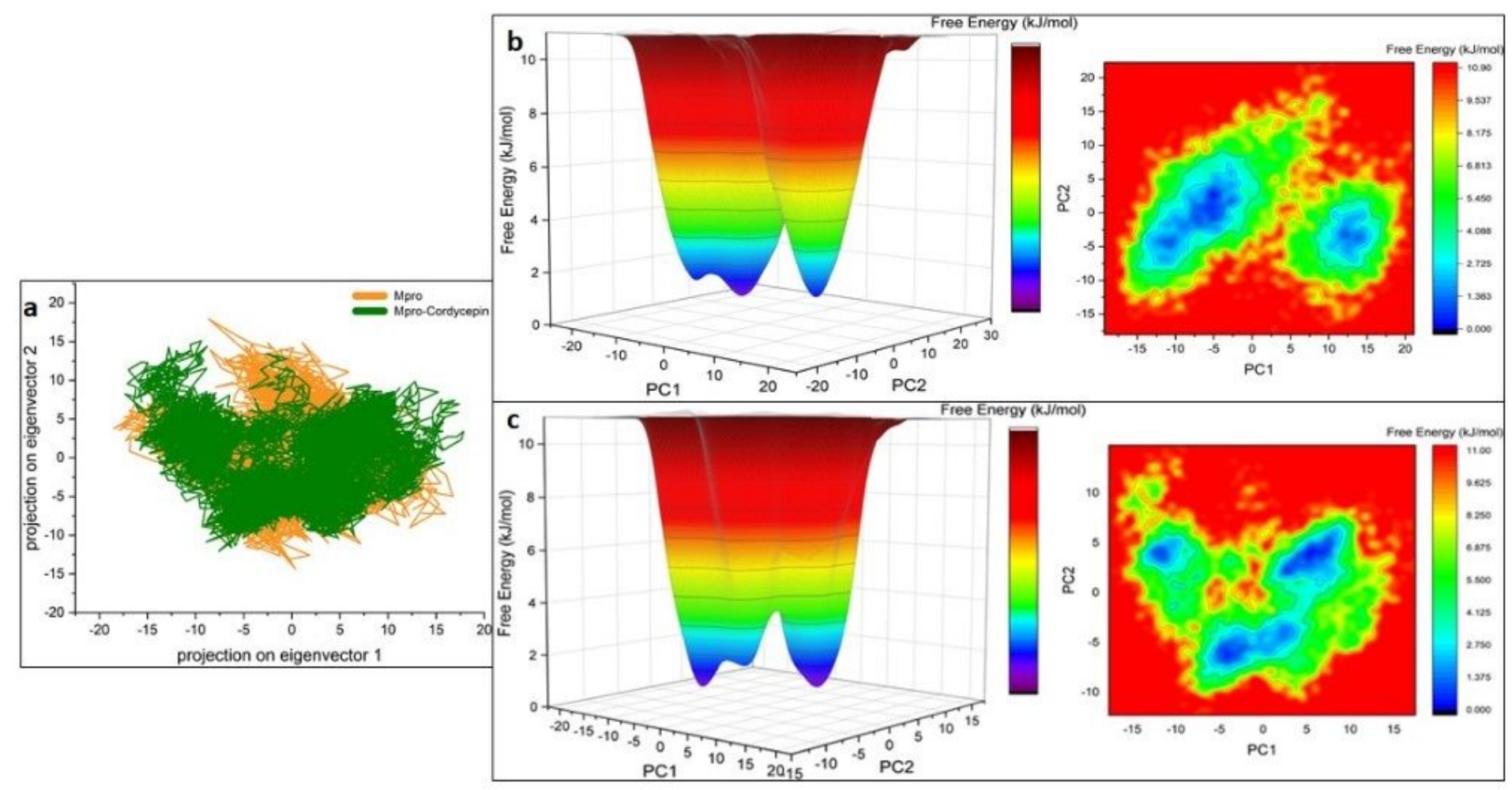

Figure 4

(a) The PCA of the cordycepin unbound and bound complex of Mpro. The graphical representation of the free energy landscape of the (b) apo and (c) cordycepin bound complex of Mpro.

LMK-Cor-1

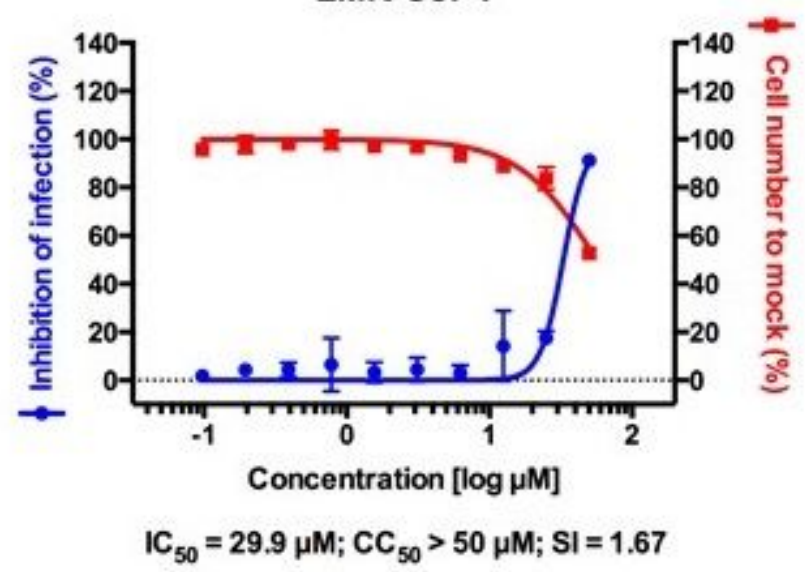

Figure 5

Dose-response curve analysis by immunofluorescence for cordycepin. The blue squares represent inhibition of SARS-CoV-2 infection (\%), and the red triangles represent cell viability (\%). Means \pm SD were calculated from duplicate experiments. 